\title{
Phenotyping open-pollinated maize varieties for environments with low nitrogen availability
}

\section{Camila Baptista do Amaral, Gustavo Hugo Ferreira de Oliveira \& Gustavo Vitti Môro}

To cite this article: Camila Baptista do Amaral, Gustavo Hugo Ferreira de Oliveira \& Gustavo Vitti Môro (2018) Phenotyping open-pollinated maize varieties for environments with low nitrogen availability, Archives of Agronomy and Soil Science, 64:10, 1465-1472, DOI: 10.1080/03650340.2018.1442574

To link to this article: https://doi.org/10.1080/03650340.2018.1442574

Accepted author version posted online: 16 Feb 2018.

Published online: 24 Feb 2018.

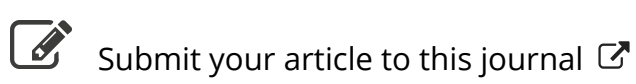

Џ Article views: 40

View Crossmark data $₫$ 


\title{
Phenotyping open-pollinated maize varieties for environments with low nitrogen availability
}

\author{
Camila Baptista do Amaral (D) ${ }^{a}$, Gustavo Hugo Ferreira de Oliveira (D) ${ }^{b}$ \\ and Gustavo Vitti Môro (iD) ${ }^{a}$
}

aDepartament of Plant Production, Faculdade de Ciências Agrárias e Veterinárias, UNESP - Univ Estadual Paulista,

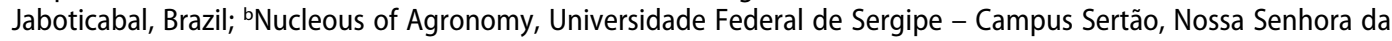
Glória, Brazil

\begin{abstract}
The high nitrogen nutrient requirement of maize is a major production constraint in areas that have a low availability of soil nitrogen. A 2-year field experiment was conducted to characterize open-pollinated varieties of maize by identifying possible sources of variability targeting low $\mathrm{N}$ environments. Twelve experimental varieties and two checks, AL Avaré and Ipanema, were cultivated under high and low nitrogen levels and evaluated for chlorophyll content index, lodging, prolificacy and grain yield. The results indicate that the applied nitrogen resulted in differences in the chlorophyll content index between environments. Nitrogen level affected the percentage of lodged plants of varieties K and L. Grain yield and lodging were the traits that most affected genotypic variability, and $17 \%$ of the studied varieties were considered as superior due to higher lodging-resistance and higher grain yield.
\end{abstract}

\section{ARTICLE HISTORY}

Received 14 November 2017 Accepted 14 February 2018

\section{KEYWORDS}

Zea mays L; plant breeding; gt biplot; abiotic stress

\section{Introduction}

Nitrogen $(\mathrm{N})$ is the major nutrient taken up by maize (Zea mays) and the main constituent of chlorophyll (Wasaya et al. 2017). For this reason, N plays a key role in important agronomic traits, such as lodging, grain yield, and prolificacy. Shi et al. (2016) reported that increased stalk resistance under adequate $\mathrm{N}$ supply, resulted in less lodged plants. Akhtar et al. (2015) studied the nitrogen fertilization effect on maize and concluded that the nutrient had significant effect on increasing grain yield. Prolificacy, defined as ears produced per plant, is an important secondary trait for breeding under low $\mathrm{N}$ conditions (Talabi et al. 2017) since it results in higher grain yield.

Selection for high yielding maize genotypes is typically conducted in environments that are not limiting for N (Badu-Apraku et al. 2012). However, sub-optimal soil nitrogen availability constitutes an important restriction to crop production in several countries (Hu et al. 2008), which makes developing cultivars adapted to low $\mathrm{N}$ condition a necessity for maize breeding programs. The best methodology to select genotypes for low $\mathrm{N}$ environments is to compare the performance of these genotypes in environments with high and low $\mathrm{N}$ availability (Han et al. 2015), to identify genotypes carrying genes associated with tolerance to low $\mathrm{N}$ that can be used in breeding programs to obtain superior and $\mathrm{N}$ efficient cultivars.

The development of superior cultivars depends on accurate characterization of the genotypes, which is only possible in the presence of genetic variability. Open-pollinated varieties are less 
productive than modern cultivars such as hybrids, however, their complex genetic structure makes them an important source of genes related to tolerance to abiotic stress (Coimbra et al. 2010). The objective of this study was to characterize open-pollinated varieties of maize and identifying possible sources of variability targeting low $\mathrm{N}$ environments.

\section{Material and methods}

\section{Experimental site}

The experiments were conducted in Jaboticabal, SP, Brazil $\left(21^{\circ} 14^{\prime} 33^{\prime \prime} \mathrm{S}, 48^{\circ} 17^{\prime} 10^{\prime \prime} \mathrm{W}\right.$, and $565 \mathrm{~m}$ above sea level), in the first season of $2015 / 2016$ and the first season of $2016 / 2017$. The experimental soil is characterized as eutroferric red Oxisol in both areas. The regional climate is classified as AW type (savanna with dry winter) according to Köppen. The area was maintained under traditional cultivation system, and maize was sowed in 2012/2013, 2013/2014 and 2014/2015.

Before the experiments were initiated, soil samples were collected in 10 points per experimental area in the $0-20 \mathrm{~cm}$ layer and analysis were performed according to Raij and Quaggio (1983). The results for both harvests are shown in Table 1, as well as the accumulated rainfall in the periods.

\section{Treatments and experimental design}

Twelve open-pollinated experimental varieties and two checks were evaluated in this study. The experimental varieties were obtained following the procedure described by Oliveira et al. (2016) from 158 elite maize lines obtained from Cimmyt and Embrapa, which were divided in 12 groups according to origin and time to maturity. The checks were the commercial varieties Ipanema and AL Avaré. AL Avaré features high resistance to lodging and high yield potential, while Ipanema is known by having a high developed root system.

The two different experiments consisted of cultivating the 14 maize varieties in two soils with contrasting $\mathrm{N}$ availability, low and high, in each period. All experiments were fertilized with $24 \mathrm{~kg} \mathrm{ha}^{-1} \mathrm{~N}, 84 \mathrm{~kg} \mathrm{ha}^{-1} \mathrm{P}_{2} \mathrm{O}_{5}$ and $48 \mathrm{~kg} \mathrm{ha}^{-1} \mathrm{~K}_{2} \mathrm{O}$ at sowing, using the formula 08-28-16 as source. In addition, the high $\mathrm{N}$ experiments were covered with $120 \mathrm{~kg} \mathrm{ha}^{-1}$ of $\mathrm{N}$ via urea, applied continuously next to the seeding line during the growth stage of 4-5 fully expanded leaves. The $2016 / 2017$ experiment also received $25 \mathrm{~kg} \mathrm{ha}^{-1} \mathrm{KCl}$ due to low potassium level, besides cover $\mathrm{N}$ fertilization.

The experiments followed a randomized complete block design, with five replicates. Each plot consisted of two $5 \mathrm{~m}$-long rows, spaced $0.5 \mathrm{~m}$ between rows and $28 \mathrm{~cm}$ between plants in the row, totaling 28 plants per plot. The plant density obtained was 56,000 plants ha ${ }^{-1}$. In 2015/2016 experiment seeds were sown on 18 November 2015, and harvested on 15 April 2016, while in 2016/2017 experiment seeds were sown on 23 November 2016, and harvested on 27 March 2017. Supplementary irrigation was not needed, since all the water requirement was supplied by the rainfall (Table 1$)$.

\section{Traits evaluated and statistical analyses}

At flowering, chlorophyll content index was measured at the middle third of the leaf above the ear using the CM-200-Opti-Sciences equipment. At maturity, lodging (broken below the ear or leaning more than 45 degrees from the vertical) was recorded for each plot and expressed as percentage of the total number of plants in the plot. After physiological maturity, the ears of both rows of the plot were hand-harvested; the kernels were separated and weighed to determine moisture content. The grain yield was adjusted to $13 \%$ grain moisture and corrected by covariance of ideal stand for 56,000 plants $\mathrm{ha}^{-1}$. Prolificacy was given by the ratio between total number of ears per plot and number of plants per plot. 
Table 1. Results from the soil analyses of layer $0-20 \mathrm{~cm}$, performed before the installation of the experiment, and accumulated rainfall during the conduction of the experiment.

\begin{tabular}{|c|c|c|}
\hline Soil parameters & $2015 / 2016$ & $2016 / 2017$ \\
\hline $\mathrm{pH}\left(\mathrm{CaCl}_{2}\right)$ & 6.3 & 5.5 \\
\hline Organic matter $\left(\mathrm{g} \mathrm{dm}^{-3}\right)$ & 25.5 & 25.0 \\
\hline$P\left(\right.$ resin) $\left(\mathrm{mg} \mathrm{dm}^{-3}\right)$ & 32.0 & 35.0 \\
\hline $\mathrm{S}\left(\mathrm{mg} \mathrm{dm}{ }^{-3}\right)$ & 5.5 & 12.0 \\
\hline $\mathrm{H}+\mathrm{Al}\left(\mathrm{mmol}_{\mathrm{c}} \mathrm{dm}^{-3}\right)$ & 24.5 & 15.0 \\
\hline $\mathrm{K}\left(\mathrm{mmol}_{\mathrm{C}} \mathrm{dm}^{-3}\right)$ & 4.7 & 3.1 \\
\hline $\mathrm{Ca}\left(\mathrm{mmol}_{\mathrm{c}} \mathrm{dm}^{-3}\right)$ & 43.0 & 36.0 \\
\hline $\mathrm{Mg}\left(\mathrm{mmol}_{\mathrm{c}} \mathrm{dm}^{-3}\right)$ & 15.5 & 15.0 \\
\hline $\operatorname{CTC}\left(\mathrm{mmol}_{\mathrm{C}} \mathrm{dm}^{-3}\right)$ & 97.7 & 69.3 \\
\hline V (\%) & 73 & 78 \\
\hline \multicolumn{3}{|l|}{ Accumulated rainfall } \\
\hline From sowing to cover fertilization (mm) & 387.4 & 127.2 \\
\hline From cover fertilization to flowering (mm) & 479.9 & 261.8 \\
\hline From flowering to physiological maturation (mm) & 357.3 & 301.6 \\
\hline Total rainfall $(\mathrm{mm})$ & $1,224.6$ & 690.6 \\
\hline
\end{tabular}

Data were tested for normality (Cramer-von Mises normality test) using the R software (Core Team 2017), and no transformation was needed. Individual analysis of variance was carried out for each experiment separately to verify the uniformity of residual variance, followed by joint analysis of variance, considering year, $\mathrm{N}$ availability and variety as fixed effects. Tukey test was used to compare the means, and $\mathrm{t}$ test was used to compare variety individual performance between $\mathrm{N}$ levels. All these statistical analyses were performed using the PROC GLM procedure from SAS ${ }^{\mathrm{TM}}$ version 9.2 (SAS Institute, Inc 2009).

The characterization of the varieties was made using a multivariate approach to determinate the 'ranking genotypes', considering all traits in a genotype-by-trait (GT) biplot model, using standardized values of the traits. The traits were considered as the tester and the cultivars as entries. For lodging, it was used the percentage of non-lodged plant, allowing the selection of varieties with the highest value for all traits. This analysis used the model described by Paramesh et al. (2016). The GT Biplot was constructed using the package 'GGEBiplotGUI', test-centered and based on genotype metric preserving (row metric preserving).

\section{Results}

\section{Analysis of variance and means comparison}

The coefficient of determination $\left(R^{2}\right)$, for chlorophyll content index, lodging, prolificacy and grain yield was higher than 0.80 (Table 2), value considered as ideal according to Cargnelutti Filho and Storck (2007).

Only the effects of $\mathrm{N}$ levels, variety, and their interaction were considered in the analysis of variance since the year had no effect on the variety $\times \mathrm{N}$ level interaction. Nitrogen level significantly influenced the chlorophyll content index at flowering but had no effect on the other traits.

Table 2. Summary of the joint analyses of variance for chlorophyll content index (CCI), lodging (LOD), prolificacy (PROL) and grain yield (GY) of 14 maize varieties in two years, under high and low nitrogen availability.

\begin{tabular}{|c|c|c|c|c|c|}
\hline \multirow[b]{2}{*}{ Source } & \multirow[b]{2}{*}{ DF } & \multicolumn{4}{|c|}{ Mean squares } \\
\hline & & $\mathrm{CCl}$ & LOD & PROL & GY \\
\hline Nitrogen (N) & 1 & $156.11^{*}$ & $12.01^{\mathrm{ns}}$ & $0.0476^{\text {ns }}$ & $341252^{n s}$ \\
\hline Variety (V) & 13 & $347.39 * *$ & $202.08^{* *}$ & $0.147^{* *}$ & $12,543,587^{* *}$ \\
\hline $\mathrm{N} \times \mathrm{V}$ & 13 & $22.11^{\mathrm{ns}}$ & $31.56^{\mathrm{ns}}$ & $0.012^{\mathrm{ns}}$ & $278166^{\mathrm{ns}}$ \\
\hline Error & 224 & 36.74 & 23.66 & 0.016 & 529,568 \\
\hline$R^{2}$ & - & 0.90 & 0.89 & 0.90 & 0.96 \\
\hline
\end{tabular}


The varieties differ significantly for all traits, but there was no interaction between varieties and $\mathrm{N}$ levels (Table 2).

Chlorophyll content index of all varieties was $2 \%$ higher for high $\mathrm{N}$ level compared to low $\mathrm{N}$. The chlorophyll content index ranged from 50.48 to 67.15 among the studied varieties. Tukey test differentiated four varieties with significant higher chlorophyll index values, including check Ipanema, above 61.70, while five varieties had indices lower than 56.73. The varieties with the lowest values included the AL Avaré check (Table 3).

Average lodging was $4.89 \%$ and not affect by $\mathrm{N}$ level. Five experimental varieties had the highest percentage of lodged plants, ranging from 11 to $7 \%$. The lowest lodging percentage, $2 \%$, was observed for AL Avaré and similar to $50 \%$ of the experimental varieties and the other check, Ipanema (Table 3).

Similarly, $\mathrm{N}$ level did not affect prolificacy, and the plants produced, on average, one ear per plant for both $\mathrm{N}$ levels. Also, prolificacy ranged between 0.94 and 1.28 for varieties $\mathrm{G}$ and I, respectively. The checks presented intermediate values of 1.08 and 1.00 for AL Avaré and Ipanema, respectively (Table 3 ).

Also, nitrogen level did not affect grain yield, which was of $5,633 \mathrm{~kg} \mathrm{ha}^{-1}$, and the varieties showed values ranging from $4,373 \mathrm{~kg} \mathrm{ha}^{-1}$ to $6,681 \mathrm{~kg} \mathrm{ha}^{-1}$. The checks and $42 \%$ of the experimental varieties had grain yield up to $5,904 \mathrm{~kg} \mathrm{ha}^{-1}$, whereas the other varieties had values at least $603 \mathrm{~kg} \mathrm{ha}^{-1}$ lower (Table 3).

Overall, $\mathrm{N}$ level did not affect chlorophyll content index, prolificacy and grain yield of the studied varieties, when comparing within each variety; however, it affected lodging of some varieties. The lodging percentage of variety $\mathrm{K}$ increased $(\mathrm{p}<0.05)$ by $58 \%$ under low $\mathrm{N}$, while variety $L$ decreased $(p<0.01)$ by $49 \%$ in the same condition (Figure 1$)$. The other varieties were not affected by $\mathrm{N}$ level.

\section{GT biplot}

The mean performance of chlorophyll content index, percentage of non-lodged plants, prolificacy and grain yield under low $\mathrm{N}$ levels were used to identify the varieties with the best performance.

The principal components PC1 and PC2 described as AXIS 1 and AXIS 2, respectively, explained 83.23\% of the total variation observed among the traits (Figure 2). The varieties considered as ideal were varieties $D$ and $E$, allocated at the innermost concentric circle with an arrow, followed by the check AL Avaré. The check Ipanema

Table 3. Means of chlorophyll content index $(\mathrm{CCl})$, lodging (LOD, \%), prolificacy (PROL, $\left.\mathrm{n}^{\circ}\right)$ and grain yield $\left(\mathrm{GY}, \mathrm{kg} \mathrm{ha}^{-\mathrm{a}}\right)$ of 14 maize varieties in two years, under high (HN) and low (LN) nitrogen availability.

\begin{tabular}{llcccc}
\hline \multirow{4}{*}{ Nitrogen } & & $\mathrm{CCl}$ & LOD & PROL & GY \\
& LN & 57.58 & 4.68 & 1.00 & 5,598 \\
& HN & 59.08 & 5.10 & 1.03 & 5,668 \\
& A & $57.22 \mathrm{bc}^{\mathrm{a}}$ & $2 \mathrm{e}$ & $1.03 \mathrm{bc}$ & $6,297 \mathrm{a}$ \\
& B & $54.22 \mathrm{~cd}$ & $2 \mathrm{e}$ & $1.04 \mathrm{bc}$ & $6,194 \mathrm{a}$ \\
& C & $56.73 \mathrm{bcd}$ & $4 \mathrm{cde}$ & $1.05 \mathrm{bc}$ & $6,224 \mathrm{a}$ \\
& D & $57.20 \mathrm{bc}$ & $2 \mathrm{e}$ & $0.96 \mathrm{bc}$ & $6,587 \mathrm{a}$ \\
& E & $58.17 \mathrm{bc}$ & $2 \mathrm{de}$ & $0.97 \mathrm{bc}$ & $6,570 \mathrm{a}$ \\
& F & $61.77 \mathrm{ab}$ & $9 \mathrm{ab}$ & $1.01 \mathrm{bc}$ & $5,014 \mathrm{~cd}$ \\
& G & $58.68 \mathrm{bc}$ & $7 \mathrm{abcd}$ & $0.94 \mathrm{c}$ & $4,789 \mathrm{~cd}$ \\
& H & $67.15 \mathrm{a}$ & $3 \mathrm{cde}$ & $1.00 \mathrm{bc}$ & $4,987 \mathrm{~cd}$ \\
& I & $50.48 \mathrm{~d}$ & $11 \mathrm{a}$ & $1.28 \mathrm{a}$ & $4,959 \mathrm{~cd}$ \\
& J & $54.42 \mathrm{~cd}$ & $3 \mathrm{cde}$ & $0.95 \mathrm{bc}$ & $4,373 \mathrm{~d}$ \\
& K & $62.54 \mathrm{ab}$ & $8 \mathrm{abc}$ & $0.97 \mathrm{bc}$ & $4,982 \mathrm{~cd}$ \\
& L & $60.18 \mathrm{bc}$ & $8 \mathrm{abc}$ & $0.96 \mathrm{bc}$ & $5,301 \mathrm{bc}$ \\
Standard error & AL Avaré & $56.15 \mathrm{bcd}$ & $2 \mathrm{e}$ & $1.08 \mathrm{~b}$ & $6,681 \mathrm{a}$ \\
& Ipanema & $61.70 \mathrm{ab}$ & $4 \mathrm{bcde}$ & $1.00 \mathrm{bc}$ & $5,904 \mathrm{ab}$ \\
\hline
\end{tabular}

${ }^{\mathrm{a}}$ Means followed by the same letter did not differ based on Tukey's test. 


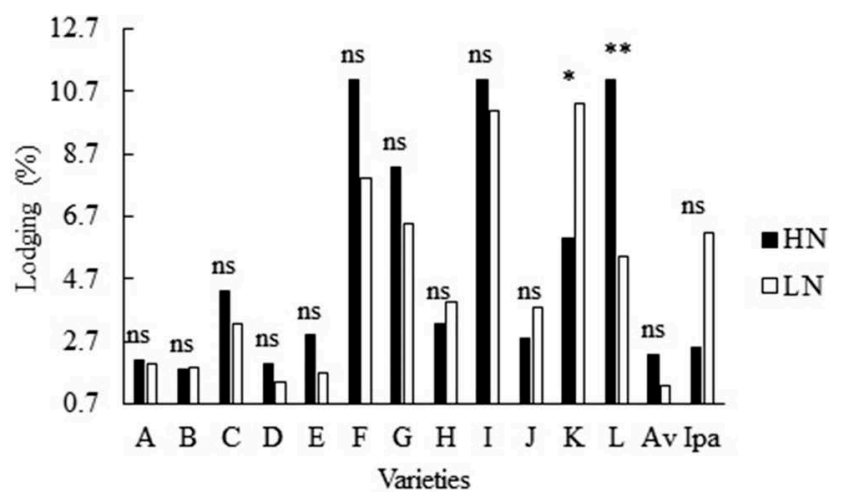

Figure 1. Means of lodged plants (\%) of 14 varieties under low level (LN) and high level (HN) of nitrogen. ** and*: significant at $1 \%$ and $5 \%$ by the $\mathrm{F}$ test, respectively. Av: AL Avaré. Ipa: Ipanema.

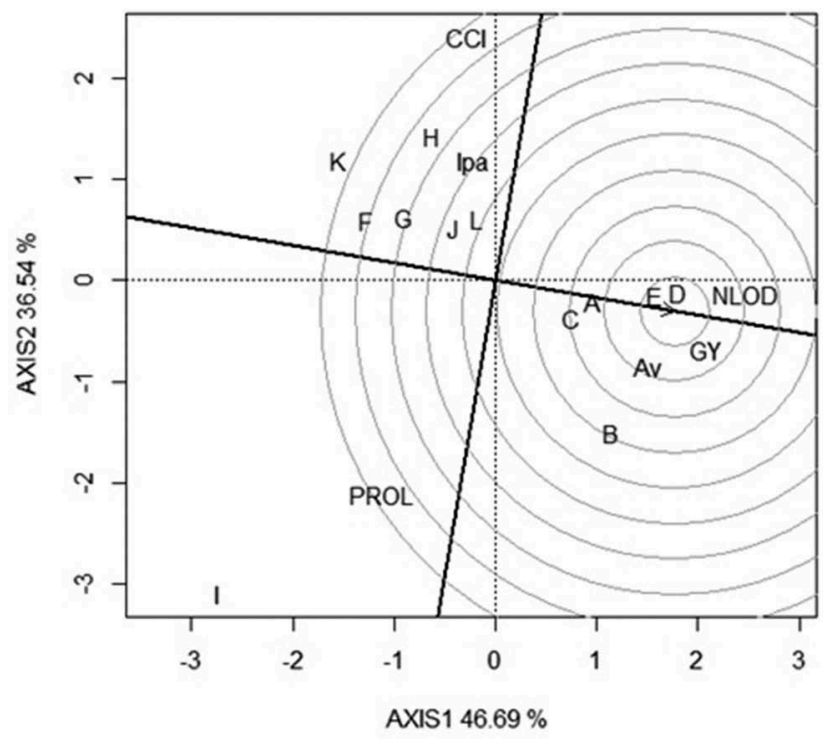

Figure 2. A vector view of genotype $x$ trait biplot showing the ranking of 14 maize varieties for chlorophyll content index (CCI), percentage of non-lodged plants (NLOD), prolificacy (PROL) and grain yield (GY) under low nitrogen availability.

$\mathrm{Av}=\mathrm{AL}$ Avaré. Ipa = Ipanema.

was allocated in the seventh concentric circles. Among all studied varieties, 58\% are outside the concentric circles and considered as "non-ideal". Grain yield and percentage of non-lodged plants were the traits that most affected the varieties.

\section{Discussion}

$\mathrm{R}^{2}$ values obtained indicate that variability is due to genotype, and not to environment, as well good experimental precision (Cargnelutti Filho and Storck 2007) and a high probability of selection on genetic traits that may be heritable.

Nitrogen is an essential nutrient that plays a key role in the chlorophyll content, as part of the molecule itself and in its synthesis (Wasaya et al. 2017) and therefore, the chlorophyll index is expected to increase when $\mathrm{N}$ levels in the soil are high. Wei et al. (2016) evaluated the response of 
maize to field conditions with and without $\mathrm{N}$ fertilizers and reported that the leaf chlorophyll concentration decreased under low $\mathrm{N}$ compared to high $\mathrm{N}$. To this end, the increase in chlorophyll content also indicates that the $\mathrm{N}$ applied in this study was able to distinguish between the environments for this trait.

Because chlorophyll plays a major role in photosynthesis, higher values of chlorophyll index are often associated with higher grain yield. Széles et al. (2012) reported strong positive phenotypic correlation between chlorophyll content at flowering and grain yield, and between $\mathrm{N}$ levels and chlorophyll content. Al-Naggar et al. (2015) studied the effect of four increasing $\mathrm{N}$ doses on chlorophyll content index, also measured by CCM-200, and on grain yield per plant of 15 diallel maize crosses, and found values ranging from 28.9 to 56.4 for chlorophyll index and 87.8 to $163.8 \mathrm{~g}$ per plant for grain yield. Despite the effect on chlorophyll content index, the different $\mathrm{N}$ levels used in this study were not sufficient to affect the other traits studied.

Considering only the genotypic effect, the varieties studied showed difference for all traits. Genotypic variability among quantitative traits of different maize genotypes have been widely reported (Serpolay-Besson et al. 2014; Yang et al. 2016), and it is a prerequisite for the selection process.

Interaction between maize hybrids and $\mathrm{N}$ levels are shown in many studies, indicating that these genotypes are recommended for high or low N environments (Han et al. 2015). However, Semagn et al. (2014) demonstrated that the open-pollinated varieties are constituted by a high number of genotypes leading to large variability within the population, implying in high ability to maintain performance across multiple environments (Mansfield and Mumm 2014). In this case, the complex structure of the varieties confers the ability to maintain the average performance, regardless of $\mathrm{N}$ level, contrary to what happens for hybrids. Likewise, Ferro et al. (2007) studied maize landraces and observed no differences on individual means when $\mathrm{N}$ was applied to the crop, evidencing that populations constituted by a large number of genotypes are usually less responsive to environmental changes. The results of this study support the finding described by Ferro et al. (2007), since $\mathrm{N}$ had no effect on the individual means of the varieties.

Nitrogen application can increase lodging-resistance, but this effect is not absolute for all genotypes. Shi et al. (2016) evaluated the effect of different $\mathrm{N}$ rates on maize genotypes and reported that $\mathrm{N}$ can improve the quality of the stalk, which leads to higher lodging-resistance, but this effect was observed only for the lodging-susceptible genotype. On the other hand, $\mathrm{N}$ application can increase plant height (Carpici et al. 2010), which also increases lodging.

The differential performance for chlorophyll content index, lodging, prolificacy and grain yield indicates a significant difference between the studied varieties. Usually, open-pollinated varieties are obtained by population breeding methods that increase the frequency of favorable alleles maintaining the genetic variability (Avdikos et al. 2011), and the selection is made under high $\mathrm{N}$ conditions (Badu-Apraku et al. 2012). Therefore, it is expected that the checks have a high frequency of favorable alleles, but the superior performance of the experimental varieties under low $\mathrm{N}$ suggests a higher frequency of these alleles.

The multivariate analysis showed that prolificacy and chlorophyll content index contributed less to discriminate the varieties compared to percentage of non-lodged plants and grain yield. These results contradict what is mentioned in the literature, where prolificacy is considered as an important secondary trait to improve selection in maize breeding programs targeting low- $\mathrm{N}$ environments (Bänziger and Lafitte 1997). The explanation is the reduced spacing between rows, that decreases the prolificacy in maize (Maddonni and Martínez-Bercovich 2014).

The success of maize breeding depends on maintaining the genetic variability. Talabi et al. (2017) evaluated the genetic variance and predicted gain under cycles of selection of 250 maize progenies, concluding that the lack of genetic variability is leading to slow selection progress under low $\mathrm{N}$, and that it is necessary to introgress new genotypes with favorable alleles to ensure progress from selection. Thus, the varieties identified as superior could be used as source of variability under low $\mathrm{N}$ conditions or as commercial cultivars indicated for areas with low $\mathrm{N}$ availability. 


\section{Conclusions}

We conclude that grain yield and lodging are the most suitable traits to characterize the varieties under low $\mathrm{N}$ level, since chlorophyll content index and prolificacy had little influence to explain the variability in the evaluated genotypes. Nitrogen level had no effect on the individual performance of varieties, except for lodging, which can increase or decrease under high $\mathrm{N}$ level depending on the genotype. All varieties were considered adequate for cultivation under low $\mathrm{N}$ since their performance is not affected by $\mathrm{N}$ availability, but only $17 \%$ of the studied varieties were superior than checks due to increased percentage of non-lodged plants and increased grain yield. Therefore, these varieties can be used as source of variability for extracting inbreed lines or developing inter-varietal hybrids with increased chlorophyll content index, prolificacy and grain yield and low lodging-susceptibility, but further studies have to be conducted to evaluate the effect of the genes associated with these traits, in order to determine the more appropriate breeding strategy.

\section{Disclosure statement}

No potential conflict of interest was reported by the authors.

\section{Funding}

This work was supported by the Coordenação de Aperfeiçoamento de Pessoal de Nível Superior (CAPES).

\section{ORCID}

Camila Baptista do Amaral (iD) http://orcid.org/0000-0002-9148-8843

Gustavo Hugo Ferreira de Oliveira (iD http://orcid.org/0000-0002-3839-6261

Gustavo Vitti Môro (iD) http://orcid.org/0000-0001-7709-7814

\section{References}

Akhtar K, Afridi MZ, Akbar M, Zaheer S, Faisal S. 2015. Planting densities and nitrogen level impact on yield and yield component of maize. Pure Appl Biol. 4(2):217.

Al-Naggar AMM, Shabana R, Atta MMM, Al-Khalil TH. 2015. Regression of grain yield of maize inbred lines and their diallel crosses on elevated levels of soil-nitrogen. Int J Plant Soil Sci. 4(6):499-512.

Avdikos ID, Tsivelika N, Gallidou A, Koutsika-Sotiriou M, Traka-Mavrona E. 2011. Exploitation of heterosis through recurrent selection scheme applied in segregating generations of a tomato breeding program. Sci Hortic. 130 (4):701-707.

Badu-Apraku B, Fakorede MA, Oyekunle M, Akinwale RO. 2012. Selection of extra-early maize inbreds under low N and drought at flowering and grain-filling for hybrid production. Maydica. 56(2):29-41.

Bänziger M, Lafitte HR. 1997. Efficiency of secondary traits for improving maize for low-nitrogen target environments. Crop Sci. 37:1110-1117.

Cargnelutti Filho A, Storck L. 2007. Estatísticas de avaliação da precisão experimental em ensaios de cultivares de milho. [Evaluation statistics of the experimental precision in corn cultivar trials]. Pesq Agropec Bras. 42:17-24.

Carpici EB, Celik N, Bayram G. 2010. Yield and quality of forage maize as influenced by plant density and nitrogen rate. Turk J Field Crops. 15(2):128-132.

Coimbra RR, Miranda GV, Cruz CD, De Melo AV, Eckert FR. 2010. Caracterização e divergência genética de populações de milho resgatadas do Sudeste de Minas Gerais. [Characterization and genetic divergence of corn populations rescued from the region southeastern of Minas Gerais]. Rev Ciênc Agron. 41:159-166.

Core Team R. 2017. R: A language and environment for statistical computing. R Foundation for Statistical Computing. http://www.R-project.org

Ferro RA, Brichette I, Evgenidis G, Karamaligkas C, Moreno-González J. 2007. Variability in European maize (Zea mays L.) landraces under high and low nitrogen inputs. Genet Resour Crop Ev. 54(2):295-308.

Han M, Okamoto M, Beatty PH, Rothstein SJ, Good AG. 2015. The genetics of nitrogen use efficiency in crop plants. Annu Rev Genet. 49:269-289.

Hu K, Li B, Chen D, Zhang Y, Edis R. 2008. Simulation of nitrate leaching under irrigated maize on sandy soil in desert oasis in Inner Mongolia, China. Agric Water Manage. 95(10):1180-1188. 
Maddonni GÁ, Martínez-Bercovich J. 2014. Row spacing, landscape position, and maize grain yield. Int J Agron. 2014:1-12.

Mansfield BD, Mumm RH. 2014. Survey of plant density tolerance in US maize germplasm. Crop Sci. 1:157-173.

Oliveira GHF, Buzinaro R, Revolti LTM, Giorgenon CH, Charnai K, Resende D, Moro GV. 2016. An accurate prediction of maize crosses using diallel analysis and best linear unbiased predictor (BLUP). Chil J Agric Res. 76(3):294-299.

Paramesh M, Reddy DM, Priya MS, Sumathi P, Sudhakar P, Reddy KHP. 2016. GT biplot analysis for yield and drought related traits in mung bean (Vigna radiata L. Wilczek). Electron J Plant Breed. 7(3):538-543.

Raij BV, Quaggio JA. 1983. Métodos de análise de solo para fins de fertilidade. Campinas(SP): Instituto Agronômico de Campinas.

SAS Institute, Inc. 2009. SAS/STAT ${ }^{\circledR}$ user's guide, version 9.2. 2nd ed. Cary (N.C): SAS Institute, Inc.

Semagn K, Magorokosho C, Ogugo V, Makumbi D, Warburton ML. 2014. Genetic relationships and structure among open-pollinated maize varieties adapted to eastern and southern Africa using microsatellite markers. Mol Breed. 3:1423-1435.

Serpolay-Besson E, Giuliano S, Schermann N, Chable V. 2014. Evaluation of evolution and diversity of maize openpollinated varieties cultivated under contrasted environmental and farmers' selection pressures: a phenotypical approach. OJGen. 4(2):125.

Shi DY, Li YH, Zhang JW, Liu P, Zhao B, Dong ST. 2016. Effects of plant density and nitrogen rate on lodging-related stalk traits of summer maize. Plant Soil Environ. 62(7):299-306.

Széles AV, Megyes A, Nagy J. 2012. Irrigation and nitrogen effects on the leaf chlorophyll content and grain yield of maize in different crop years. Agric Water Manage. 107:133-144.

Talabi AO, Badu-Apraku B, Fakorede MAB. 2017. Genetic variances and relationship among traits of an early maturing maize population under drought-stress and low nitrogen environments. Crop Sci. 57(2):681-692.

Wasaya A, Tahir M, Ali H, Hussain M, Yasir TA, Sher A, ljaz M. 2017. Influence of varying tillage systems and nitrogen application on crop allometry, chlorophyll contents, biomass production and net returns of maize (Zea maysL.). Soil Tillage Res. 170:18-26.

Wei S, Wang X, Shi D, Li Y, Zhang J, Liu P, Zhao B, Dong S. 2016. The mechanisms of low nitrogen induced weakened photosynthesis in summer maize (Zea mays L.) under field conditions. Plant Physiol Biochem. 105:118-128.

Yang S, Liu Y, Zhang D, Zhang Z, Zhang J, Zhu L, Huang Y, Zho Y, Guo J, Chen J. 2016. Genetic architecture of lodging resistance revealed by genome-wide association study in maize (Zea mays L). Maydica. 61(4):1-7. 